\title{
Development of a Hybrid Bioinorganic Nanobiocatalyst: Remarkable Impact of the Immobilization Conditions on Activity and Stability of $\beta$-Galactosidase
}

\author{
Luigi Tavernini ${ }^{1}$, Oscar Romero ${ }^{1,2}, * \mathbb{D}$, Carla Aburto ${ }^{1}$, Fernando López-Gallego ${ }^{3,4}$, Andrés Illanes ${ }^{1}$ and \\ Lorena Wilson 1 ,* \\ 1 Escuela de Ingeniería Bioquímica, Pontificia Universidad Católica de Valparaíso, Avenida Brasil 2085, \\ Valparaíso 2362803, Chile; Luigi.tavernini@pucv.cl (L.T.); carla.aburto@pucv.cl (C.A.); \\ andres.illanes@pucv.cl (A.I.) \\ 2 Bioprocess Engineering and Applied Biocatalysis Group, Department of Chemical Biological and \\ Environmental Engineering, Universitat Autònoma de Barcelona, 08193 Bellaterra, Spain \\ 3 CIC biomaGUNE, Basque Research and Technology Alliance (BRTA), Paseo de Miramón 182, \\ 20014 Donostia-San Sebastián, Spain; flopez.ikerbasque@cicbiomagune.es \\ 4 Ikerbasque, Basque Foundation for Science, 48013 Bilbao, Spain \\ * Correspondence: oscarenrique.romero@uab.cat (O.R.); lorena.wilson@pucv.cl (L.W.)
}

check for updates

Citation: Tavernini, L.; Romero, O.; Aburto, C.; López-Gallego, F.; Illanes, A.; Wilson, L. Development of a Hybrid Bioinorganic Nanobiocatalyst: Remarkable Impact of the Immobilization Conditions on Activity and Stability of $\beta$-Galactosidase. Molecules 2021, 26, 4152. https:// doi.org/10.3390/molecules26144152

Academic Editor: Teofil Jesionowski

Received: 7 June 2021

Accepted: 5 July 2021

Published: 8 July 2021

Publisher's Note: MDPI stays neutral with regard to jurisdictional claims in published maps and institutional affiliations.

Copyright: (c) 2021 by the authors. Licensee MDPI, Basel, Switzerland. This article is an open access article distributed under the terms and conditions of the Creative Commons Attribution (CC BY) license (https:/ / creativecommons.org/licenses/by/ $4.0 /)$.

\begin{abstract}
Hybrid bioinorganic biocatalysts have received much attention due to their simple synthesis, high efficiency, and structural features that favor enzyme activity and stability. The present work introduces a biomineralization strategy for the formation of hybrid nanocrystals from $\beta$ galactosidase. The effects of the immobilization conditions were studied, identifying the important effect of metal ions and $\mathrm{pH}$ on the immobilization yield and the recovered activity. For a deeper understanding of the biomineralization process, an in silico study was carried out to identify the ion binding sites at the different conditions. The selected $\beta$-galactosidase nanocrystals showed high specific activity $(35,000 \mathrm{IU} / \mathrm{g}$ biocatalyst) and remarkable thermal stability with a half-life 11 times higher than the soluble enzyme. The nanobiocatalyst was successfully tested for the synthesis of galacto-oligosaccharides, achieving an outstanding performance, showing no signs of diffusional limitations. Thus, a new, simple, biocompatible and inexpensive nanobiocatalyst was produced with high enzyme recovery (82\%), exhibiting high specific activity and high stability, with promising industrial applications.
\end{abstract}

Keywords: $\beta$-galactosidase; nanoimmobilization; biomineralization

\section{Introduction}

The need to improve the economic and catalytic performance of enzymes for industrial application has driven the development of numerous immobilization strategies aimed at enhancing biocatalyst stability (either thermal or mechanical) to re-use the enzymes in multiple operational cycles [1]. In addition, recent advances in enzyme immobilization not only allow their reuse, but also improve and modulate their catalytic properties $[2,3]$. Nevertheless, immobilization often impacts negatively on enzyme activity by causing inactivation due to the harsh immobilization conditions, and by adding inert mass in the form of a carrier [4]. Consequently, much effort has been spent in optimizing the immobilization protocols to reduce these negative effects and making the advantages of immobilization prevail. In this direction, during the last decades there has been growing interest in the synthesis and use of nanostructured materials for enzyme immobilization. Nanostructured materials display a large surface-to-volume ratio and highly adjustable surface characteristics, allowing an increased enzyme loading per unit mass, and immobilization conditions tailored for the specific requirements of the proteins [5]. The nanobiocatalysts thus developed exhibit improved immobilization efficiency, high stability, easy handling and recovery, 
as well as reduced mass transfer resistance for substrates, facilitating biotechnological applications [6]. In recent years, Ge et al. $[7,8]$ introduced an innovative immobilization strategy based on the biomineralization of metal phosphates with proteins, resulting in what has been termed hybrid organic-inorganic nanoflowers, or simply nanoflowers, due to the flower-resembling nanostructure of these biocatalysts [9]. Hybrid nanoflowers have drawn the interest of researchers owing to the large surface reaction area offered by their petal-like nanostructures, increasing immobilization efficiency and substrate access, as well as stability and selectivity. Another outstanding characteristic is their very simple, eco-friendly, and cost-efficient synthesis [10-12]. The biomineralization process is carried out under mild reaction conditions at room temperature in aqueous phosphate buffer, harnessing the strong affinity of enzymes for metal ions which bind to the protein backbone via coordination interactions with reactive aminoacidic groups, forming nucleation points distributed across the protein surface $[7,13,14]$.

Many factors have been reported to affect the formation and structure of the nanoflowers, including the concentration of reagents (enzymes, phosphate, and metal ions), $\mathrm{pH}$, temperature, and biomineralization time [15]. However, to date little is known about how these factors affect the catalytic properties of the biocatalyst, such as expressed activity and stability [12,16]. Therefore, immobilization conditions must be thoroughly investigated to determine those yielding the optimal biocatalytic performance. This is crucial for enzymes for industrial use, where having a biocatalyst with good catalytic performance must be balanced with the economic viability of the process. This is the case of $\beta$-galactosidase ( $\beta$-gal), a well-known enzyme with wide applications in the production of lactose-free products or prebiotics, such as galacto-oligosaccharide (GOS), lactulose and other syrups [17-20]. The need to improve the economic and catalytic performance of $\beta$-galactosidases for industrial application has driven the development of numerous immobilization strategies [21]. Despite the growing interest, the immobilization of $\beta$ galactosidase as bioinorganic nanoflowers has received little attention, and not much emphasis has been placed on the immobilization conditions, nor on its application in synthetic reactions [22-24].

The aim of this work was to evaluate the influence of the immobilization condition on the catalytic properties of the nanobiocatalyst, focusing on the effects of metal ions, salt/protein ratio, biomineralization time and $\mathrm{pH}$. Furthermore, in order to get insight into the biomineralization process, a computational study was carried out to identify the potential nucleation sites of the enzyme at different immobilization conditions. Finally, the nanobiocatalyst was assessed in terms of its expressed activity, thermostability and its performance in the synthesis of GOS.

\section{Results and Discussion}

\subsection{Metal Ion Screening}

A screening was conducted with $\mathrm{Cu}^{2+}, \mathrm{Mg}^{2+}, \mathrm{Zn}^{2+}, \mathrm{Co}^{2+}, \mathrm{Fe}^{2+}, \mathrm{Ca}^{2+}$ to determine those ions suitable for the immobilization of $\beta$-gal as hybrid bioinorganic nanocrystals. The results in terms of immobilization yield (IY) led to the selection of $\mathrm{Ca}^{2+}$ for the following research stages, given the substantial advantage shown by this ion over the other ions assayed, obtaining an IY of $29.4 \%$, which exceeds by five times the IY of the next best ion $\left(\mathrm{Cu}^{2+}\right)$ (Table S1, Supplementary Materials).

\subsection{Biomineralization of $\beta$-Galactosidase with Calcium}

Once the calcium ion was selected, the study of biomineralization at $\mathrm{pH} 7.4$ was conducted using $\mathrm{CaCl}_{2} /$ protein ratios of $115,230,290,345,400$ and $460 \mathrm{mmol}_{\mathrm{CaCl}_{2}} / \mathrm{g}_{\text {protein }}$, and contact times of 30, 60 and $120 \mathrm{~min}$. The results obtained in terms of immobilization yield (IY) and specific activity (SA) (Figure 1) showed an optimum in the range from 290 to $345 \mathrm{mmol}_{\mathrm{CaCl}_{2}} / \mathrm{g}_{\text {protein }}$ in the case of IY, and around $290 \mathrm{mmol}_{\mathrm{CaCl}_{2}} / \mathrm{g}_{\text {protein }}$ in the case of SA, regardless of the biomineralization time evaluated. Maximum IY was $44 \%$ at $345 \mathrm{mmol}_{\mathrm{CaCl}_{2}} / \mathrm{g}_{\text {protein, }}$, which is very close to the value of $43 \%$ obtained at 
$290 \mathrm{mmol}_{\mathrm{CaCl}_{2}} / \mathrm{g}_{\text {protein }}$ with a negligible difference between 30 and $60 \mathrm{~min}$ of biomineralization. A peak of $21,300 \mathrm{IU} / \mathrm{g}_{\text {biocatalyst }}$ was achieved unambiguously at $290 \mathrm{mmol}_{\mathrm{CaCl}_{2}} / \mathrm{g}_{\text {protein }}$, again showing no significant difference between 30 and $60 \mathrm{~min}$ of biomineralization. Overall IY and SA slightly decreased at a biomineralization time of $120 \mathrm{~min}$, in comparison to 30 and $60 \mathrm{~min}$.
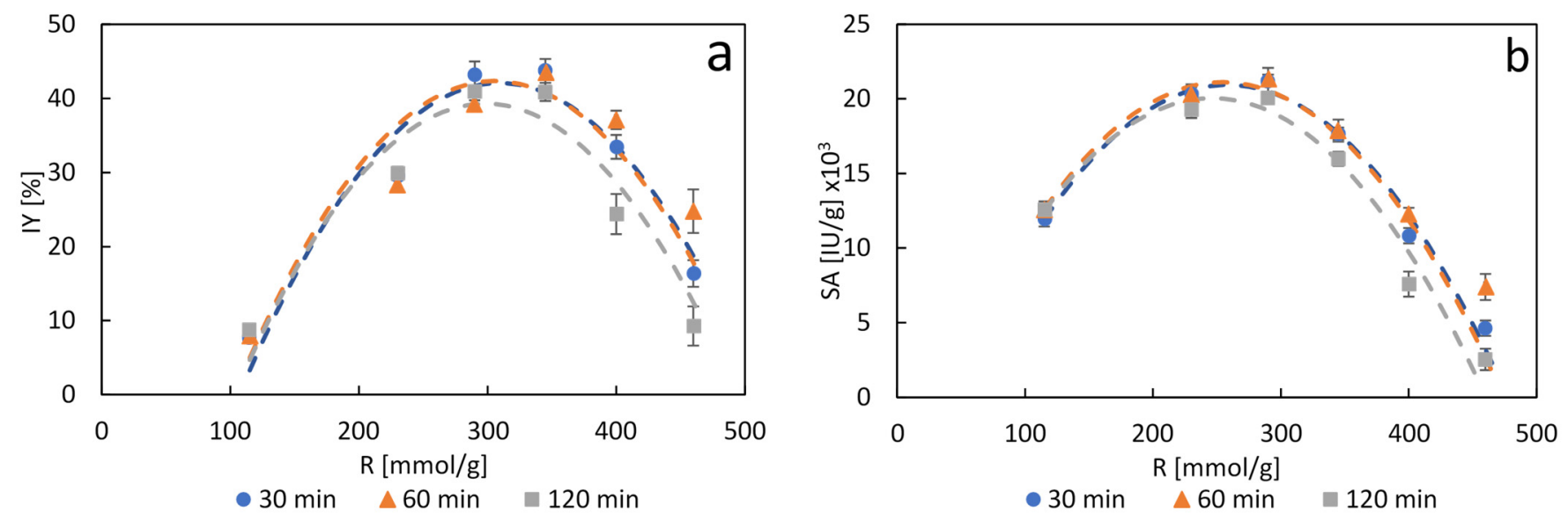

Figure 1. Immobilization yield (IY) (a) and specific activity (SA) (b) of calcium-phosphate nanocrystals of $\beta$-galactosidase produced at $\mathrm{pH} 7.4$ at $\mathrm{CaCl}_{2}$ / protein ratios (R) of 115, 230, 290, 345, 400 and $460 \mathrm{mmol}_{\mathrm{CaCl}_{2}} / \mathrm{g}_{\text {protein }}$ for $30 \mathrm{~min}$, $60 \mathrm{~min}$, and $120 \mathrm{~min}$ of biomineralization time. Data are presented as mean \pm margin of error, $n=2$. Dashed lines represent the model for each data set according to Equation (S1) (Supplementary Materials).

Remarkably, IY and SA followed the same trend, and hence exhibited the same optimum, unlike most other immobilization methods, particularly the support-based ones, in which enzyme load per unit mass of carrier usually results in a clear compromise between IY and SA. A very close trend to the one shown in Figure 1 can be observed for protein immobilization (Figure S1, Supplementary Materials) being the optimum protein immobilization yield obtained between 290 and $345 \mathrm{mmol}_{\mathrm{CaCl}_{2}} / \mathrm{g}_{\text {protein }}(62 \%$ in nanocrystals produced after $60 \mathrm{~min}$ of biomineralization, and 50\% in nanocrystals produced after both 30 and 120 min of biomineralization). Diffusional limitations may be playing a role on the activity drop in the $\mathrm{CaCl}_{2}$ /protein range beyond the optimum (around $\left.290 \mathrm{mmol}_{\mathrm{CaCl}_{2}} / \mathrm{g}_{\text {protein }}\right)$, although, as seen in Figure S1, protein immobilization followed a similar trend to the SA and IY in Figure 1, showing that at higher $\mathrm{CaCl}_{2} /$ protein ratios less protein was being biomineralized. This is possibly due to the formation of more naked calcium-phosphate salt at the expense of the protein-calcium-phosphate complex. On the other hand, the detrimental effect observed at $120 \mathrm{~min}$ of biomineralization may be caused by modifications of the enzyme's structure leading to activity loss, or due to increasing diffusional restrictions brought about by more compact and complex structures hindering substrate access. It has been widely reported that the structure complexity of nanoflowers increase with incubation time [11,15].

The results were arranged into a full 32 factorial experimental design to simplify analysis and subjected to an analysis of variance (ANOVA) to assess the statistical significance of the variables $\mathrm{CaCl}_{2}$ / protein ratio and biomineralization time (see Supplementary Materials). Considering a level of significance of $\alpha=0.05$, both variables, as well as their combination, exerted a statistically significant effect on IY and SA of the $\beta$-gal nanocrystals, validating the previous observations drawn from Figure 1.

\subsection{Effect of $\mathrm{pH}$ on the Biomineralization of $\beta$-Galactosidase}

Enzyme immobilization as hybrid bioinorganic nanoflowers has been shown to be critically affected by $\mathrm{pH}$. Despite this, few examples of biomineralization at different $\mathrm{pHs}$ 
are described in the literature [15], motivating the present study of the effect of $\mathrm{pH}$ on biomineralization.

The effect of $\mathrm{pH}$ on $\beta$-gal biomineralization was firstly evaluated by means of prospective assays carried out at $290 \mathrm{mmol}_{\mathrm{CaCl}_{2}} / \mathrm{g}_{\text {protein }}$ for $60 \mathrm{~min}$. The results show a linear correlation in the $\mathrm{pH}$ range from 6 to 9 for both IY and SA (Figure 2a,b). Beyond $\mathrm{pH} 9.0$, a sudden drop in both parameters was observed, while at $\mathrm{pH}$ below 6.0 no activity was recovered. Quite remarkably, IY increases from 0 at $\mathrm{pH} 6.0$ to $72 \%$ at $\mathrm{pH} 9.0$, demonstrating the strong effect of $\mathrm{pH}$ on the biomineralization process.
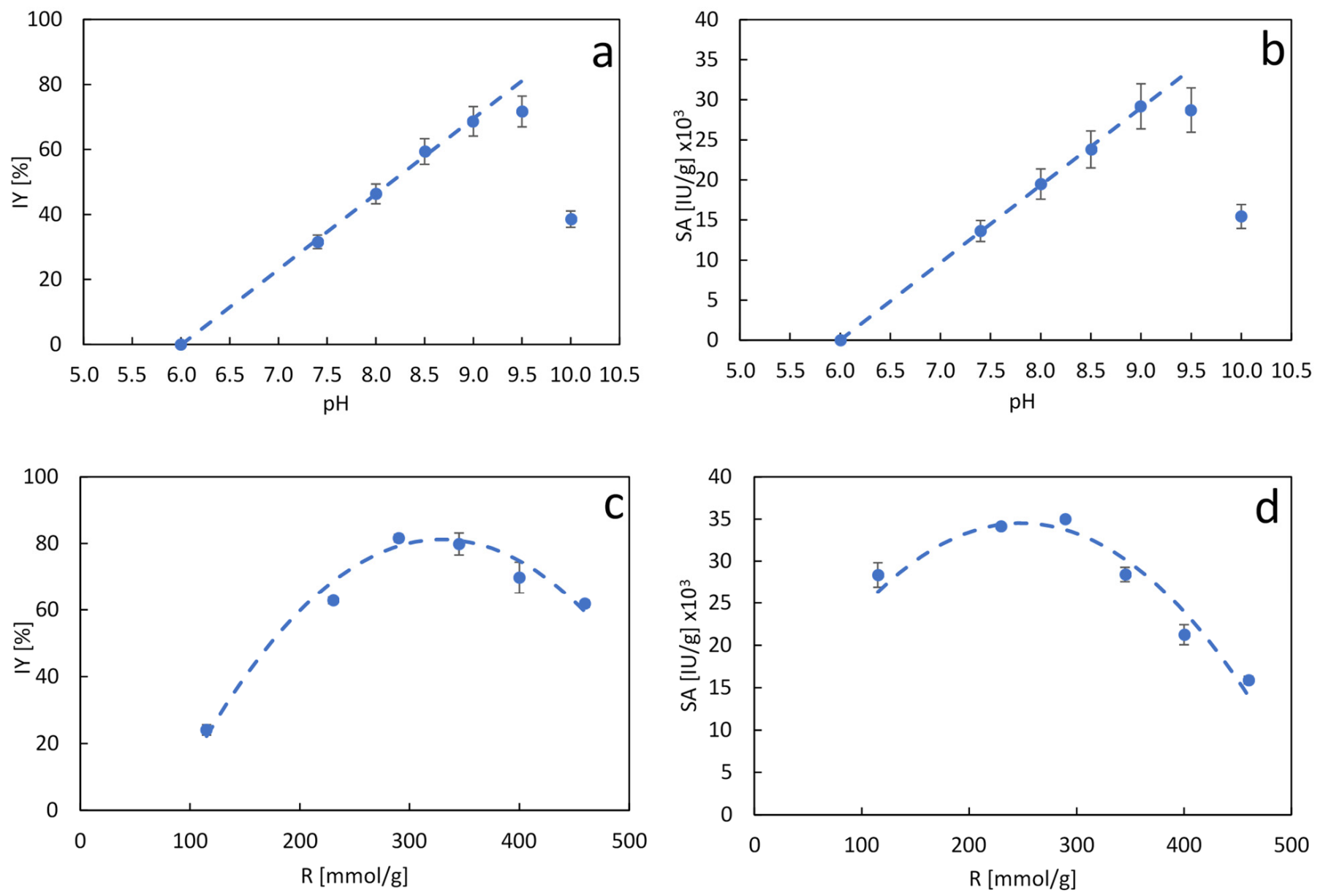

Figure 2. Immobilization yield (IY) (a) and specific activity (SA) (b) of calcium-phosphate $\beta$-galactosidase nanocrystals produced at a $\mathrm{CaCl}_{2} /$ protein ratio of $290 \mathrm{mmol}_{\mathrm{CaCl}_{2}} / \mathrm{g}_{\text {protein }}$ for $60 \mathrm{~min}$ at different $\mathrm{pHs}$. Immobilization yield (IY) (c) and specific activity (SA) (d) of calcium-phosphate $\beta$-galactosidase nanocrystals produced at $\mathrm{pH} 9.0$ for 60 min at different $\mathrm{CaCl}_{2}$ /protein ratios. Data are presented as mean \pm margin of error, $n=2$. Dashed lines in (c) and (d) represent the model for each data set according to Equation (S2) (Supplementary Materials).

The effect of $\mathrm{pH}$ on the formation of nanoflowers is presumably due to changes in the ionization state of the enzyme's reactive groups as well as to changes in the distribution equilibrium of the phosphate species $[13,25]$. Several authors have suggested that an increase of the net negative charge of the enzyme molecules at higher $\mathrm{pH}$ had a positive effect on the binding affinity of metal ions, promoting biomineralization by increasing nucleation points [26]. Furthermore, previous works have reported that an increase in $\mathrm{pH}$ yielded less ordered and less compact nanoflower structures [26,27]. This could favor the diffusion of substrates and products in and out from the biocatalyst, explaining the increase in specific activity at higher $\mathrm{pHs}$. 
These results led to the formulation of a new experimental run at $\mathrm{pH} 9.0$, considering the same $\mathrm{CaCl}_{2}$ /protein ratio range assayed at $\mathrm{pH} 7.4$ but considering only $60 \mathrm{~min}$ of biomineralization. As control, we incubated the soluble enzyme at the biomineralization $\mathrm{pH}$ in order to detect potential activity loss. As a result, we observed that the enzyme remained fully active for up to $3 \mathrm{~h}$ of incubation in PBS at $\mathrm{pH} 9$. Figure $2 \mathrm{c}, \mathrm{d}$ displays the behavior of IY and SA in relation to the $\mathrm{CaCl}_{2} /$ protein ratio as a result of the biomineralization of $\beta$-gal with calcium-PBS at $\mathrm{pH} 9.0$ for $60 \mathrm{~min}$. As was the case for the biomineralization at $\mathrm{pH} 7.4$, production of the $\beta$-gal nanocrystals at $\mathrm{pH} 9.0$ exhibited a quadratic correlation of both IY and SA with respect to the $\mathrm{CaCl}_{2}$ / protein ratio, with a clear maximum in the vicinity of $290 \mathrm{mmol}_{\mathrm{CaCl}_{2}} / \mathrm{g}$ protein. The maximum values of SA and IY were $35,000 \mathrm{IU} / \mathrm{g}_{\text {biocatalyst }}$ and $81.7 \%$ respectively, showing a remarkable improvement over previous results at $\mathrm{pH} 7.4$, confirming the successful optimization in the biocatalyst preparation. These data were modeled according to the quadratic expression (model and parameters are shown in Supplementary Information). ANOVA testing showed that the regression model is highly significant, supporting the critical effect of both $\mathrm{pH}$ and $\mathrm{CaCl}_{2} /$ protein ratio on the biomineralization of $\beta$-gal.

\subsection{Thermal Stability of the $\beta$-Galactosidase Nanocrystals}

The thermal stability of selected $\beta$-galactosidase nanocrystals was evaluated under nonreactive conditions $100 \mathrm{mM}$ PBS pH 7.0 at $50^{\circ} \mathrm{C}$. Thermal stability of free $\beta$-gal was also carried out for comparative purposes. To do so, the stability tests were performed for the biocatalysts made at $\mathrm{pH} 7.4$ and 9.0, considering 115, 290, and $460 \mathrm{mmol}_{\mathrm{CaCl}_{2}} / \mathrm{g}_{\text {protein, }}$, as these $\mathrm{CaCl}_{2} /$ protein ratios. As can be seen from Figure $3 \mathrm{a}, \mathrm{b}$, nanocrystals in general showed higher stability than soluble $\beta$-gal, the latter being almost completely inactivated after $100 \mathrm{~h}$ of incubation, while the $\beta$-gal nanocrystals made at $\mathrm{pH} 7.4$ and $\mathrm{pH} 9.0$ retained over $20 \%$ and $40 \%$ of activity, respectively, after the same incubation time. Another relevant finding derived from the inactivation kinetics of the $\beta$-gal nanocrystals was that stability increased proportionally to the $\mathrm{CaCl}_{2}$ /protein ratio. This could be explained by the fact that an increase in $\mathrm{CaCl}_{2}$ / protein ratio generates more compact and complex structures (Figure 3), creating a protective effect on the enzyme structure and the activity thereof. Parameters of the mathematical models for the inactivation kinetics are shown in Sup. Information. The ANOVA and coefficients of determination prove the statistical significance of the models, and the parameters half-life time, SF and CP were determined therefrom.

Figure $3 c$,d show the half-life times and the catalytic potential of different $\beta$-gal bioinorganic nanocrystals compared to the free enzyme. $\beta$-gal nanocrystals synthesized at $\mathrm{pH} 9.0$ exhibit overall higher half-life times than the soluble enzyme and the nanocrystals produced at $\mathrm{pH} 7.4$, respectively. A SF of 14.7 was achieved at the most stable condition ( $\mathrm{pH}$ 9.0, $460 \mathrm{mmol}_{\mathrm{CaCl}_{2}} / \mathrm{g}_{\text {protein }}$ and $60 \mathrm{~min}$ of biomineralization), and the best immobilization condition showed a SF of $11.6\left(\mathrm{pH} 9.0,290 \mathrm{mmol}_{\mathrm{CaCl}_{2}} / \mathrm{g}_{\text {protein }}, 60 \mathrm{~min}\right.$ ). These results are substantially better than those reported with other immobilization methods, in Table 1 a comparison of the results of different methods of immobilization for $A$. oryzae $\beta$-galactosidase are shown. The developed biocatalyst exhibited both high SA and high stability as opposed to other works reviewed that usually yield a trade-off between these two parameters (Table 1). 
Table 1. Comparative results of immobilization of Aspergillus oryzae $\beta$-galactosidase by different methods and thermal stability of the resulting biocatalysts.

\begin{tabular}{|c|c|c|c|c|c|}
\hline $\begin{array}{c}\text { Immobilization } \\
\text { Methods }\end{array}$ & Support/Precipitant & $\begin{array}{l}\text { Immobilization } \\
\text { Yield [\%] }\end{array}$ & $\begin{array}{l}\text { Specific Activity } \\
{\left[\text { IIU/g }^{1}\right.}\end{array}$ & $\begin{array}{l}\text { Stability } \\
\text { Factor }\end{array}$ & Reference \\
\hline Biomineralization & - & 81.7 & 35,000 & 11.6 & This work \\
\hline \multirow{11}{*}{ Covalent bonding } & Glyoxyl-agarose & 85 & 2500 & 1.5 & [28] \\
\hline & Amino-glyoxyl-agarose & 57 & 7700 & 2.3 & [28] \\
\hline & Carboxy-glyoxyl-agarose & 13.14 & 780 & 1.3 & [28] \\
\hline & Chelate-glyoxyl-agarose & 5.13 & 455 & 1.4 & [28] \\
\hline & Chitosan-epichlorohydrin & 54 & 2951 & 1.8 & [29] \\
\hline & Amino-glyoxyl-agarose & 40 & 2294 & 2.5 & [29] \\
\hline & Chitosan-glutaraldehyde & 70.5 & 3070 & 3.9 & {$[30]$} \\
\hline & Alginate-cellulose beads & 70 & n.r. & 3.4 & [31] \\
\hline & Chitosan-glutaraldehyde & 18.4 & n.r. & 1.2 & [32] \\
\hline & Cotton fibers-PEI & 80 & n.r. & 10.3 & [33] \\
\hline & Sodium alginate & n.r. & n.r. & 2.8 & {$[34]$} \\
\hline \multirow{4}{*}{ CLEAs } & - & 100 & 64,000 & 1.1 & [35] \\
\hline & - & 90 & 44,560 & 2.3 & [35] \\
\hline & - & 13.5 & Not reported & 1.2 & [32] \\
\hline & - & 30 & 15,000 & 1.3 & [36] \\
\hline
\end{tabular}

${ }^{1}$ Activity determined using o-NPG as substrate. n.r.: not reported.
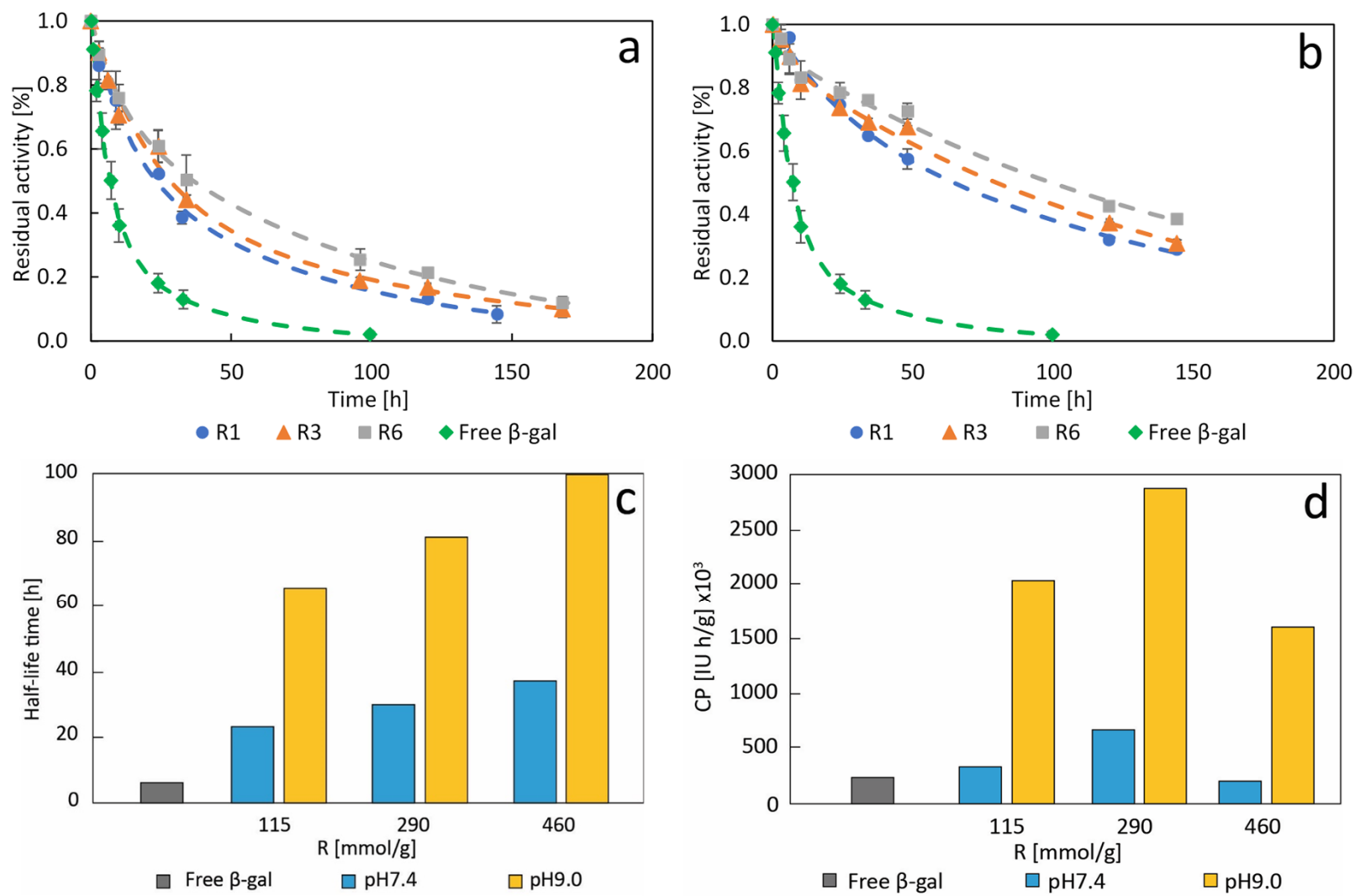

Figure 3. Inactivation kinetics at $50{ }^{\circ} \mathrm{C}$ and $\mathrm{pH} 7.0$ of free $\beta$-galactosidase $(\beta$-gal) and $\beta$-galactosidase nanocrystals produced at pH $7.4(\mathbf{a})$, and at $\mathrm{pH} 9.0$ (b) after $60 \mathrm{~min}$ of mineralization time at $\mathrm{CaCl}_{2} /$ protein ratios of $115 \mathrm{mmol}_{\mathrm{CaCl}_{2}} / \mathrm{g}_{\text {protein }}(\mathrm{R} 1)$, $290 \mathrm{mmol}_{\mathrm{CaCl}_{2}} / \mathrm{g}_{\text {protein }}(\mathrm{R} 3)$, and $460 \mathrm{mmol}_{\mathrm{CaCl}_{2}} / \mathrm{g}_{\text {protein }}(\mathrm{R} 6)$. Data are presented as mean \pm margin of error, $n=2$. The dashed lines represent the models. Half-life time $(\mathbf{c})$ and catalytic potential (CP) (d) of free $\beta$-galactosidase $(\beta$-gal) and $\beta$-galactosidase nanocrystals produced after $60 \mathrm{~min}$ of mineralization time at $\mathrm{pH} 7.4$ ( $\mathrm{pH} 7.4$, blue column) and $\mathrm{pH} 9.0$ ( $\mathrm{pH}$ 9.0, yellow column) at different $\mathrm{CaCl}_{2}$ / protein ratios (R). The catalytic potential was evaluated at $30 \%$ residual activity. 
The catalytic potential (CP) denotes the total catalytic capacity of the biocatalyst along its lifespan and allows the merging of activity of the immobilized biocatalysts and their stability into one compounded parameter [37]. Figure $3 \mathrm{~d}$ shows the CP of different biocatalysts made under different conditions and compares them with the free enzyme. As shown in all previous results, the $\beta$-gal nanocrystals produced at $\mathrm{pH} 9.0$ performed markedly better than those made at $\mathrm{pH}$ 7.4. The highest $\mathrm{CP}$ was obtained at $290 \mathrm{mmol}_{\mathrm{CaCl}_{2}} / \mathrm{g}_{\text {protein }}$ with a value of $2.868 \times 10^{3} \mathrm{IU} \cdot \mathrm{h} / \mathrm{g}_{\text {biocatalyst, }}$ as compared to the $245.3 \times 10^{3} \mathrm{IU} \cdot \mathrm{h} / \mathrm{g}_{\text {biocatalyst }}$ of the free enzyme, highlighting the importance of optimization of the immobilization conditions (see Figure $3 \mathrm{~d}$ ).

\subsection{In Silico Prediction of Metal-Ion Binding Regions}

In order to get insight into the biomineralization process, potential nucleation sites for $\mathrm{Ca}^{2+}$ were identified based on the structural information of $\beta$-gal (PDB ID: 4IUG) and a server for predicting metal ion binding sites (MIB at http:/ / bioinfo.cmu.edu.tw /MIB/ (accessed on 11 June 2020)) [38]. Based on this methodology, potential sites of nucleation have been previously determined for different bioinorganic composites [13,39]. A great number of $\mathrm{Ca}^{2+}$ nucleation sites were predicted for $\beta$-gal, which may explain the fast and efficient formation of the bioinorganic composites. The predicted binding sites for $\beta$-gal are shown in Figure 4 and the Table S2 (Supplementary Materials), and as expected many of them involve amino acids usually found at calcium binding sites such as: Asp, Glu and Asn. It is also observed that no binding sites are located near the catalytic pocket, which supports the high recovered enzyme activity upon the biomineralization process.

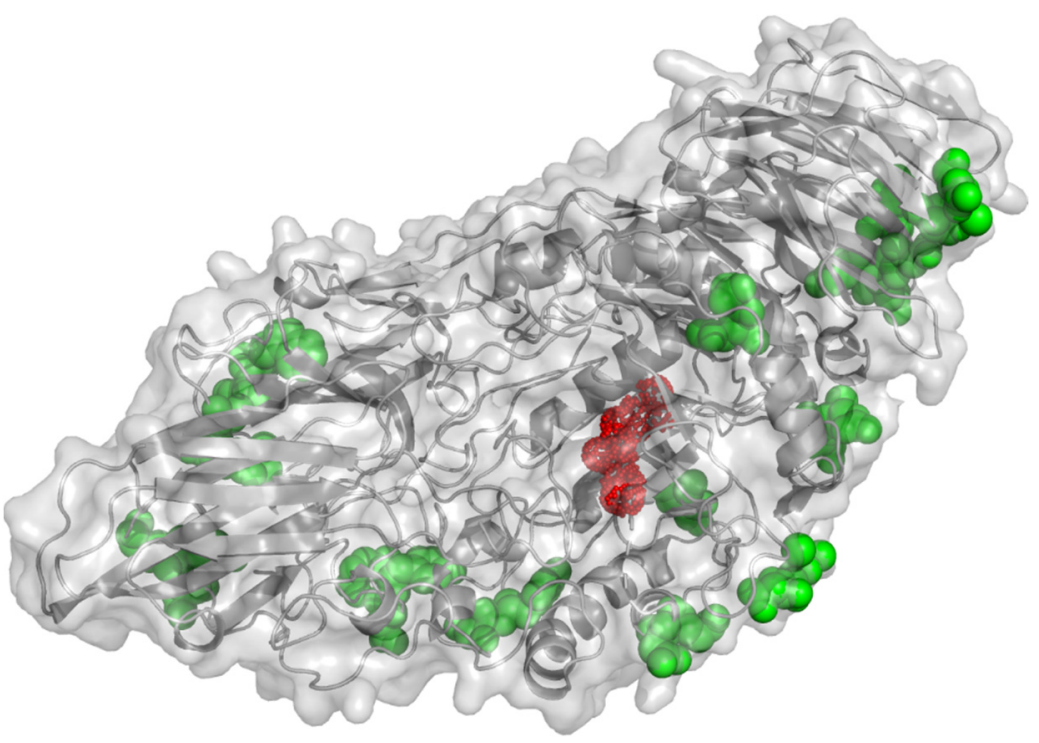

Figure 4. Predicted nucleation sites of calcium ions on $\beta$-galactosidase using MIB server (green) and active site of the enzyme (red).

Then, we were interested in understanding the effect of $\mathrm{pH}$ over the predicted nucleation points. To that aim, we determined the protonation states of each residue of $\beta$-gal at both pH 7.4 and 9.0 using the PlayMolecule repository [40]. The same nucleation sites were identified at both $\mathrm{pHs}$, with no significant difference in their binding scores (Table S2, Supplementary Materials). This is probably because none of the amino acids involved in calcium binding undergo changes in their protonation state between $\mathrm{pH} 7.4$ and 9.0 [38,40], suggesting that the difference in biomineralization at varying $\mathrm{pHs}$ may rather be due to changes in the distribution equilibrium of phosphate species $\left(\mathrm{H}_{2} \mathrm{PO}_{4}{ }^{-} ; \mathrm{HPO}_{4}{ }^{2-}\right)$.

Crystallization and precipitation of calcium phosphates is a complex phenomenon driven by both thermodynamic and kinetic interactions and affected by variables such 
as composition, supersaturation, temperature, $\mathrm{pH}$, ionic strength and stoichiometric ratios [41].

The effect of $\mathrm{pH}$ is prevalent on the solution speciation and the net charge of the mineral surface. In alkaline solutions, the mineral surface is negatively charged and ions, such as $\mathrm{H}^{+}$and $\mathrm{Ca}^{2+}$, bind to the surface forming complex structures [41]. Calcium phosphate speciation has been determined to involve no less than eleven variants, the most prominent of which are monocalcium phosphate, dicalcium phosphate, and apatites including octacalcium phosphate, amorphous calcium phosphate, hydroxyapatite and calcium deficient apatite [42]. Interactions with 3D-folded biomacromolecules such as $\beta$-gal add more complexity to the phenomenon, and thorough research must be conducted to elucidate the mechanisms involved, a task beyond the scope of this work.

\subsection{Characterization of the $\beta$-galactosidase Nanocrystals}

SEM imagery was taken for samples of the $\beta$-gal nanocrystals made at $\mathrm{pH} 9.0$ for $60 \mathrm{~min}$ and at different $\mathrm{CaCl}_{2}$ / protein ratios (Figure 5). Most studies describe a three-step process: in a first stage, metal ions bind to proteins via coordination groups forming nucleation points for the metal-phosphate crystals; in a second growth stage, the protein-metalphosphate complexes aggregate into larger petal-like agglomerates, which finally develop into full multilayered flower-like structures in a third stage of anisotropic growth $[9,43]$. Many studies have looked into the kinetics of the process, confirming the presence of irregular nanocrystals at very early stages $(0.1 \mathrm{~h}$ to $2 \mathrm{~h})$, followed by flower-mimicking nanostructures with increasing incubation time ( $3 \mathrm{~h}$ to $24 \mathrm{~h}$ ), yielding compact nanoflowers after about $24 \mathrm{~h}$, with the time-frames varying in each particular case $[44,45]$. Figure 5 shows a development process as a function of the $\mathrm{CaCl}_{2}$ / protein ratio. As in the kinetics of the process, Figure 5a-c shows the effect of calcium/protein ratio on the morphology of the bioinorganic composites. While a ratio of $115 \mathrm{mmol} \mathrm{CaCl}_{2} / \mathrm{g}_{\text {protein }}$ forms nanoparticles, a much higher ratio (460 $\mathrm{mmol}_{\mathrm{CaCl}_{2}} / \mathrm{g}_{\text {protein }}$ ) forms flower-like structures. Rectangular microcrystal of approximately $2 \times 10 \mu \mathrm{m}$ were found at intermediate ratio, indicating that the $\mathrm{CaCl}_{2}$ / protein clearly influences the hierarchical assembly of bioinorganic nanocrystals. Other structures, beside nanoflowers, have been reported for calcium-based nanocrystals as those found in this work [46]. The stability tests in Figure 3 suggest that the higher structural complexity associated with higher $\mathrm{CaCl}_{2}$ /protein ratios also plays a role in enhancing stability, possibly due to bigger and more robust structures exerting a protective effect on the enzyme.
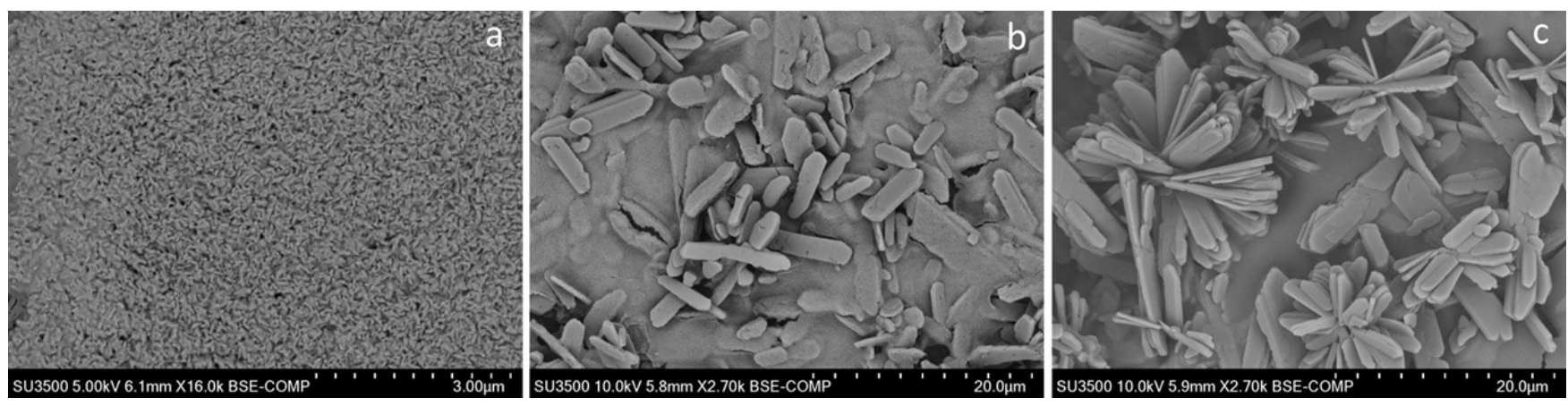

Figure 5. SEM photography of the calcium-phosphate $\beta$-galactosidase nanocrystals produced at $\mathrm{pH} 9.0$ for $60 \mathrm{~min}$ at $\mathrm{CaCl}_{2} /$ protein ratios of $115 \mathrm{mmol}_{\mathrm{CaCl}_{2}} / \mathrm{g}_{\text {protein }}(\mathbf{a}), 290 \mathrm{mmol}_{\mathrm{CaCl}_{2}} / \mathrm{g}_{\text {protein }}(\mathbf{b})$, and $460 \mathrm{mmol}_{\mathrm{CaCl}_{2}} / \mathrm{g}_{\text {protein }}$ (c).

\subsection{Synthesis of Galacto-Oligosaccharides}

The bioinorganic $\beta$-gal nanocrystals were tested as catalysts in the synthesis of GOS. The results in terms of percentage of total saccharides can be seen in Figure 6. GOS of varying length, namely GOS-3, GOS-4 and GOS-5 were considered as total GOS. In Figure 6, the profiles of the hydrolysis products glucose and galactose are also represented, 
and the remaining lactose. The kinetics of GOS synthesis with free $\beta$-gal (Figure 6a) and with $\beta$-gal nanocrystals (Figure $6 \mathrm{~b}$ ) mirror each other almost exactly, both reaching a maximum GOS yield (30\%) at about $40 \mathrm{~min}$. These results agreed with those obtained by Vera et al. (2012) at the same conditions using the same soluble $\beta$-gal from $A$. oryzae. GOS conversion yields obtained with $\beta$-gal from $A$. oryzae using other immobilization methods usually range from 15 to $27 \%$ [47], which highlights the good performance of the biocatalysts herein presented. These are remarkable results since immobilized enzymes usually show poorer performance than the free enzymes due to diffusional limitations [48]. This supports the notion that nanoflowers, or nanocrystals, are not subjected to significant mass transfer limitations due to their large reactive area, suggesting that the vast majority of the immobilized enzymes are highly exposed to the bulk of the reaction. The lower performance of immobilized biocatalysts in relation to the soluble enzymes is a feature that reduces productivity, therefore compromising the competitiveness of these biocatalysts and sets out serious concerns about their potential use as catalysts for industrial processes.
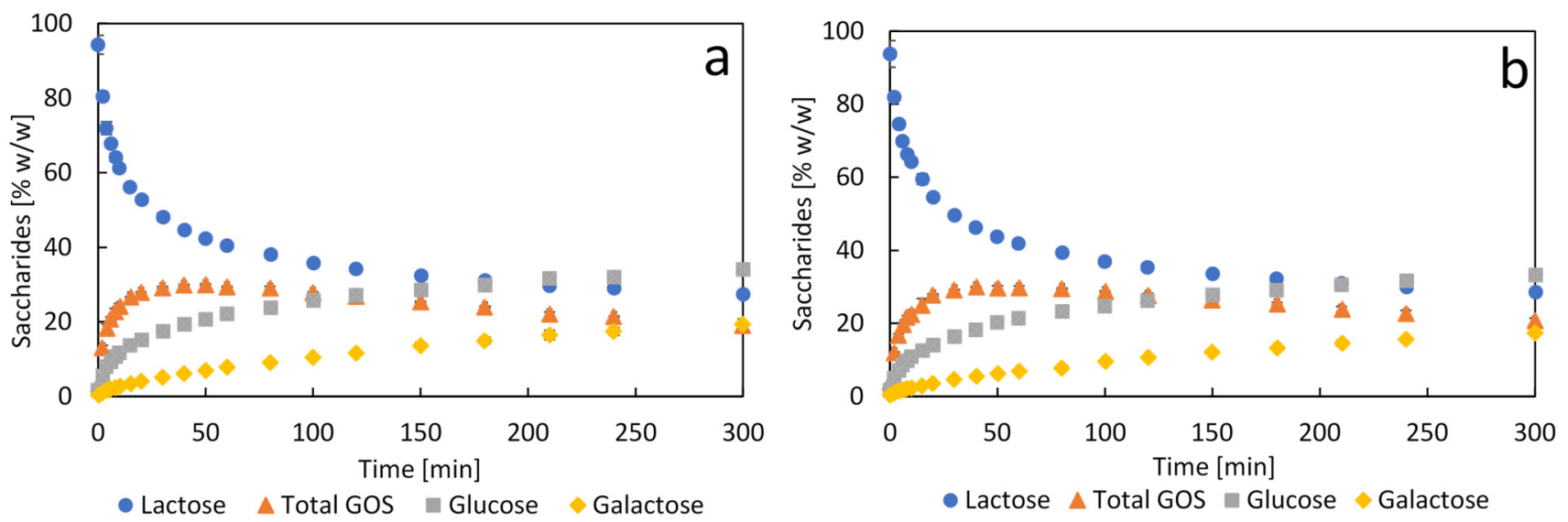

Figure 6. Kinetics of synthesis of galacto-oligosaccharides with free (a) and bioinorganic nanocrystals (b) of $\beta$-galactosidase. Synthesis conditions: $100 \mathrm{IU} / \mathrm{g}_{\text {lactose, }}$ lactose $50 \% \mathrm{w} / \mathrm{w}$ in citrate-phosphate buffer $\mathrm{pH} 4.5$ and $50{ }^{\circ} \mathrm{C}$. Data are presented as mean \pm margin of error, $n=2$.

The $\beta$-gal nanocrystals showed no signs of diffusional limitations and no negative impact on productivity. Furthermore, considering the high catalytic potential of the $\beta$-gal nanocrystals, as reflected on a SF value of 11.6 , it is safe to conclude that the biocatalyst developed has promising prospects for GOS synthesis, and possibly for lactulose synthesis and lactose hydrolysis, as well. Additionally, the biocompatibility of calcium opens up multiple applications for this type of biocatalyst in the areas of functional foods and biomedicine $[49,50]$.

\section{Materials and Methods}

\subsection{Chemicals and Reagents}

Commercial $\beta$-galactosidase Enzeco Fungal Lactase from A. oryzae ( $\beta$-gal) (EC 3.2.1.23) with a specific activity (SA) of 152,361 $\pm 4755 \mathrm{IU} / \mathrm{g}_{\text {protein }}$ was supplied by Enzyme Development Corporation, EDC (New York, NY, USA). All chemicals were purchased from Sigma Aldrich (St. Louis, MO, USA) at the highest purity available.

\subsection{Hydrolytic Activity of $\beta$-Galactosidase}

One international unit of hydrolytic activity of $\beta$-galactosidase (IU) was defined as the amount of enzyme releasing $1 \mu \mathrm{mol}$ of o-NP per min as a result of the hydrolysis of o-NPG at $\mathrm{pH} 7.0$ and $40{ }^{\circ} \mathrm{C}$. Molar extinction coefficient of o-NP was $2.21 \mathrm{mM}^{-1} \mathrm{~cm}^{-1}$ at $420 \mathrm{~nm}$. 


\subsection{Biomineralization of $\beta$-Galactosidase}

The biomineralization procedure was based on the method reported by Escobar et al. [13] where $400 \mu \mathrm{L}$ of a metal salt solution $\left(\mathrm{CuSO}_{4}, \mathrm{MgSO}_{4}, \mathrm{ZnCl}_{2}, \mathrm{CoCl}_{2}\right.$, $\mathrm{FeSO}_{4}, \mathrm{CaCl}_{2}$ ) were added under magnetic stirring to $5 \mathrm{~mL}$ of a $1 \mathrm{mg} / \mathrm{mL}$ enzyme solution in phosphate-buffered saline (PBS) made from $50 \mathrm{mM}$ sodium phosphate and $150 \mathrm{mM}$ $\mathrm{NaCl}$ at room temperature. Biomineralization time $(\mathrm{min}, \mathrm{t}), \mathrm{pH}$ of the PBS solution, and metal/protein ratio (mmol of metal salt/g of contacted protein, $\mathrm{R}$ ) were established as required by the experimental conditions under study (details in Supplementary Materials). The resulting biomineral suspension was subjected to centrifugation at 10,000 rpm for $15 \mathrm{~min}$ and then rinsed and resuspended in $5 \mathrm{~mL}$ of $25 \mathrm{mM}$ potassium phosphate buffer $\mathrm{pH} 7.0$, repeating the process two further times. The $\beta$-gal nanocrystals were then stored at $4{ }^{\circ} \mathrm{C}$ in rinsing buffer.

All results were evaluated in terms of specific activity (SA) and immobilization yield (IY) both defined according to:

$$
\begin{aligned}
S A & =A_{E} / M_{b} \cdot 100 \\
I Y & =A_{E} / A_{I} \cdot 100
\end{aligned}
$$

where $A_{E}$ is the total activity expressed by the enzyme or immobilized biocatalyst (IU), $M_{b}$ is the dry weight of the biocatalyst (g), and $A_{I}$ is the initial activity subjected to immobilization (IU).

SA was expressed in international units of hydrolytic activity per $g$ of protein in the case of free $\beta$-gal (IU/g protein), and in international units of hydrolytic activity per $g$ of biocatalyst in the case of the $\beta$-gal bioinorganic nanocrystals (IU/giocatalyst).

\subsection{Thermal Stability of the $\beta$-Galactosidase Bioinorganic Nanocrystals}

A selection of the bioinorganic $\beta$-gal nanocrystals developed and free $\beta$-gal were subjected to thermal inactivation at $50^{\circ} \mathrm{C}$ in $100 \mathrm{mM}$ PBS pH 7.0. The resulting kinetics of inactivation were modeled according to a series biphasic inactivation mechanism without residual activity [37]. The model equations are described in Supporting Information. Additionally, half-life time $\left(\mathrm{t}_{1 / 2}\right)$, stabilization factor $(\mathrm{SF})$ and catalytic potential (CP) were determined for the $\beta$-gal nanocrystals from the thermal inactivation kinetics. The description and equations for these parameters is presented in Supplementary Materials.

\subsection{In Silico Prediction of Calcium Binding Sites}

The possible sites of nucleation of $\beta$-gal (PDB: 4IUG) were determined using the fragment transformation method available as a public server at MIB (http://bioinfo.cmu. edu.tw/MIB/introduction (accessed on 11 June 2020)) [38]. The protonation states of each residue at $\mathrm{pH} 7.4$ and 9.0 was determined using the ProteinPrepare at PlayMolecule repository [40]. Both protonation states were evaluated in MIB server for the prediction of metal binding sites for $\mathrm{Ca}^{2+}$.

\subsection{Characterization of the $\beta$-Galactosidase Bioinorganic Nanocrystals}

The calcium-phosphate $\beta$-gal nanocrystals were analyzed using scanning electron microscopy (SEM) using a HITACHI SU 3500 instrument. The samples were previously washed with distilled water to remove unspecific crystals from the phosphate buffer and then sputtered with gold to minimize surface charging.

\subsection{Synthesis of Galacto-Oligosaccharides}

The developed immobilized biocatalyst was tested in the synthesis of GOS along with the free $\beta$-gal for comparative purposes. The procedure and reaction conditions were based on the work by Vera et al. [51]. The reaction assays were conducted in duplicates in $150 \mathrm{~mL}$ Erlenmeyer flasks at $50{ }^{\circ} \mathrm{C}$ under magnetic stirring. Lactose monohydrate was added at $50 \% w / w(12.5 \mathrm{~g})$ in $100 \mathrm{mM}$ citrate-phosphate buffer $\mathrm{pH} 4.5$ dissolving it by heating at a temperature close to $100{ }^{\circ} \mathrm{C}$. The reaction was initiated once the free $\beta$-gal solution or 
$\beta$-gal biocatalyst was added at a ratio of $100 \mathrm{IU} / \mathrm{g}_{\text {lactose }}$. The products of the reactions were analyzed by HPLC in a Jasco RI 2031 delivery system coupled with a refractive index detector using a BP-100 $\mathrm{Ca}^{2+}$ column $(300 \mathrm{~mm} \times 7.8 \mathrm{~mm}$ ) (Benson Polymeric, Reno, NV, USA) and milli-Q water as mobile phase [51].

\section{Conclusions}

This study reports the successful immobilization of $A$. oryzae $\beta$-galactosidase as hybrid bioinorganic nanocrystals. Calcium was determined to be the most adequate metal ion for $\beta$-gal biomineralization, outperforming copper by five times in terms of immobilization yield, whereas almost negligible results were obtained with the other ions tested. Conditions such as metal/protein ratio and $\mathrm{pH}$ proved to be highly relevant. $\mathrm{CaCl}_{2} /$ protein ratio showed an optimum of both immobilization yield and specific activity in the vicinity of $290 \mathrm{mmol}_{\mathrm{CaCl}_{2}} / \mathrm{g}_{\text {protein. The metal }}$. protein ratio was also influential on the hierarchical assembling of the nanocrystals with larger, more complex and more robust structures at higher metal/protein ratios, as confirmed by SEM and the stability tests. Particularly significant was the effect of $\mathrm{pH}$, allowing an increase in the immobilization yield from 0 to $82 \%$ in the $\mathrm{pH}$ range from 6.0 to 9.0, clearly demonstrating the high importance of optimization of the immobilization conditions in the development of this types of nanobiocatalyst. The in silico analysis showed no correlation between the predicted nucleation points and shifts in the ionization state of critical reactive groups as a consequence of $\mathrm{pH}$ change. Although such correlation cannot be completely dismissed, the effect of $\mathrm{pH}$ might be rather related to variations of calcium phosphate speciation.

The developed biocatalyst showed a specific activity of 35,000 IU/g $\mathrm{g}_{\text {biocatalyst }}$, and a stability factor of 11.6 (at $50^{\circ} \mathrm{C}$ ), surpassing the results reported to date for other immobilized $\beta$-gal in which a compromise usually occurs between both parameters. Furthermore, the bioinorganic $\beta$-gal nanocrystals were successfully tested for the synthesis of GOS performing as well as the free enzymes in terms of yield and volumetric productivity, showing therefore, no signs of diffusional limitations. These features make the $\beta$-gal nanocrystals highly competitive biocatalysts for the synthesis of GOS and for other important industrial and biomedical applications.

In short, $\beta$-galactosidase immobilization as bioinorganic nanocrystals was shown to be a remarkably simple cost-efficient methodology that allows high retention of enzyme activity, producing a biocatalyst with high specific activity, high stability, and optimal performance of GOS synthesis from lactose. Furthermore, because calcium is safe and compatible as a food and pharmaceutical additive, multiple applications open up for this biocatalyst in the production of prebiotics and drug-delivery.

Supplementary Materials: Figure S1. Protein immobilization yield (IY $\mathrm{P}_{\mathrm{P}}$ ) of calcium-phosphate nanocrystals of $\beta$-galactosidase produced at $\mathrm{pH} 7.4$ for biomineralization times of $30 \mathrm{~min}$ (T30), $60 \mathrm{~min}$ (T60), and $120 \mathrm{~min}$ (T120), and salt/protein ratios (R) of 115, 230, 290, 345, 400 and $460 \mathrm{mmol}_{\mathrm{CaCl}_{2}} / \mathrm{g}_{\text {protein; }}$ Table S1. Immobilization yield of $\beta$-galactosidase bioinorganic nanocrystals using several metal ions. Biomineralization conditions: PBS pH 7.4, $230 \mathrm{mmol}_{\text {salt }} / \mathrm{g}_{\text {protein }}$, for $2 \mathrm{~h}$ at room temperature; Table S2. Binding residues and scores predicted for $\mathrm{Ca}^{+2}$ by the MIB server; Table S3. Results of the $3^{2}$ full factorial experimental design for the biomineralization of $\beta$-galactosidase with calcium-phosphate. Variables: time ( $\mathrm{t}$ ), and salt/protein ratio (R). Response parame-ters: specific activity (SA) and immobilization yield (IY); Table S4. ANOVA test of the $3^{2}$ full factorial experimental design for the biomineralization of $\beta$-galactosidase with calcium-phosphate. Variables: time ( $\mathrm{t}$ ), and salt/protein ratio (R). Response pa-rameter: specific activity (SA); Table S5. ANOVA test of the $3^{2}$ full factorial experimental design for the biomineralization of $\beta$-galactosidase with calcium-phosphate. Variables: time ( $t$ ), and salt/protein ratio (R). Response pa-rameter: immobilization yield (IY); Table S6. Parameters of the models developed for the immobilization yield (IY) and specific activ-ity (SA) of the biomineralization of $\beta$-galactosidase with calcium-phosphate according to Equation (S4); Table S7. Parameters, $p$-values, and coefficients of determination $\left(\mathrm{R}^{2}\right)$ of the models developed for the immobilization yield (IY) and specific activity (SA) resulting from the biomineralization of $\beta$-galactosidase at $\mathrm{pH} 9.0$ for $60 \mathrm{~min}$. The models are represented by 
Equation (S5); Table S8. Model parameters, $p$-values, and coefficients of determination of the kinetic models of inactivation of $\beta$-galactosidase nanocrystals produced at $\mathrm{pH} 7.4$ and $\mathrm{pH} 9.0$ for $60 \mathrm{~min}$ of bio-mineralization at calcium/protein ratios of $115 \mathrm{mmol}_{\mathrm{CaCl}_{2}} / \mathrm{g}_{\text {protein }}$ (R1), $290 \mathrm{mmol}_{\mathrm{CaCl}_{2}} / \mathrm{g}_{\text {protein }}$ (R3), and $460 \mathrm{mmol}_{\mathrm{CaCl}_{2}} / \mathrm{g}_{\text {protein }}$ (R6). The models correspond to the biphasic inactivation mechanism as represented by Equation (S6). Equation (S1): Multiple linear regression; Equation (S2): Regression models for the experimental designs.

Author Contributions: L.T.: investigation, writing—original draft; O.R.: investigation, visualization, writing-review and editing. C.A.: investigation; F.L.-G.: conceptualization; writing-review and editing; A.I.: writing-review and editing; L.W.: funding acquisition, supervision, writing-review and editing. All authors have read and agreed to the published version of the manuscript.

Funding: This work was supported by FONDECYT-Chile (grant number 1190709). The authors thanks María Villarroel and FONDEQUIP-CONICYT number 140079 for technical support in SEM analysis. LT acknowledges funding from PUCV for doctoral fellowship and FLG acknowledges the funding of IKERBASQUE.

Institutional Review Board Statement: Not applicable.

Informed Consent Statement: Not applicable.

Data Availability Statement: Not applicable.

Conflicts of Interest: The authors declare no conflict of interest.

Sample Availability: Samples of the compounds are not available from the authors.

\section{References}

1. Basso, A.; Serban, S. Industrial applications of immobilized Enzymes-A review. Mol. Catal. 2019, 479, 110607. [CrossRef]

2. Cowan, D.A.; Fernandez-Lafuente, R. Enhancing the functional properties of thermophilic enzymes by chemical modification and immobilization. Enzym. Microb. Technol. 2011, 49, 326-346. [CrossRef]

3. Godoy, C.A.; Romero, O.; De Las Rivas, B.; Mateo, C.; Fernandez-Lorente, G.; Guisan, J.M.; Palomo, J.M. Changes on enantioselectivity of a genetically modified thermophilic lipase by site-directed oriented immobilization. J. Mol. Catal. B Enzym. 2013, 87, 121-127. [CrossRef]

4. Sheldon, R.A. Cleas, combi-cleas and 'smart' magnetic cleas: Biocatalysis in a bio-based economy. Catalysts 2019, 9, 261. [CrossRef]

5. Misson, M.; Zhang, H.; Jin, B. Nanobiocatalyst advancements and bioprocessing applications. J. R. Soc. Interface 2015, 12, 20140891. [CrossRef]

6. Cipolatti, E.P.; Valério, A.; Henriques, R.O.; Moritz, D.E.; Ninow, J.L.; Freire, D.M.G.; Manoel, E.A.; Fernandez-Lafuente, R.; De Oliveira, D. Nanomaterials for biocatalyst immobilization-state of the art and future trends. RSC Adv. 2016, 6, 104675-104692. [CrossRef]

7. Ge, J.; Lei, J.; Zare, R.N. Protein-inorganic hybrid nanoflowers. Nat. Nanotechnol. 2012, 7, 428-432. [CrossRef] [PubMed]

8. Wu, X.; Hou, M.; Ge, J. Metal-organic frameworks and inorganic nanoflowers: A type of emerging inorganic crystal nanocarrier for enzyme immobilization. Catal. Sci. Technol. 2015, 5, 5077-5085. [CrossRef]

9. Lee, S.W.; Cheon, S.A.; Kim, M.I.; Park, T.J. Organic-inorganic hybrid nanoflowers: Types, characteristics, and future prospects. J. Nanobiotechnol. 2015, 13. [CrossRef] [PubMed]

10. Al Zoubi, W.; Kamil, M.P.; Fatimah, S.; Nisa, N.; Ko, Y.G. Recent advances in hybrid organic-inorganic materials with spatial architecture for state-of-the-art applications. Prog. Mater. Sci. 2020, 112, 100663. [CrossRef]

11. Bilal, M.; Asgher, M.; Shah, S.Z.H.; Iqbal, H.M.N. Engineering enzyme-coupled hybrid nanoflowers: The quest for optimum performance to meet biocatalytic challenges and opportunities. Int. J. Biol. Macromol. 2019, 135, 677-690. [CrossRef]

12. Shende, P.; Kasture, P.; Gaud, R.S. Nanoflowers: The future trend of nanotechnology for multi-applications. Artif. Cells Nanomed. Biotechnol. 2018, 46, 413-422. [CrossRef]

13. Escobar, S.; Velasco-Lozano, S.; Lu, C.H.; Lin, Y.F.; Mesa, M.; Bernal, C.; López-Gallego, F. Understanding the functional properties of bio-inorganic nanoflowers as biocatalysts by deciphering the metal-binding sites of enzymes. J. Mater. Chem. B 2017, 5, 4478-4486. [CrossRef]

14. Zhang, B.; Li, P.; Zhang, H.; Fan, L.; Wang, H.; Li, X.; Tian, L.; Ali, N.; Ali, Z.; Zhang, Q. Papain $/ \mathrm{Zn}_{3}\left(\mathrm{PO}_{4}\right)_{2}$ hybrid nanoflower: Preparation, characterization and its enhanced catalytic activity as an immobilized enzyme. RSC Adv. 2016, 6, 46702-46710. [CrossRef]

15. Cui, J.; Jia, S. Organic-inorganic hybrid nanoflowers: A novel host platform for immobilizing biomolecules. Coord. Chem. Rev. 2017, 352, 249-263. [CrossRef]

16. Liu, Y.; Ji, X.; He, Z. Organic-inorganic nanoflowers: From design strategy to biomedical applications. Nanoscale 2019, 11, 17179-17194. [CrossRef] [PubMed] 
17. Araya, E.; Urrutia, P.; Romero, O.; Illanes, A.; Wilson, L. Design of combined crosslinked enzyme aggregates (combi-CLEAs) of $\beta$-galactosidase and glucose isomerase for the one-pot production of fructose syrup from lactose. Food Chem. 2019, 288, 102-107. [CrossRef]

18. Misson, M.; Dai, S.; Jin, B.; Chen, B.H.; Zhang, H. Manipulation of nanofiber-based $\beta$-galactosidase nanoenvironment for enhancement of galacto-oligosaccharide production. J. Biotechnol. 2016, 222, 56-64. [CrossRef]

19. Banjanac, K.; Carević, M.; Ćorović, M.; Milivojević, A.; Prlainović, N.; Marinković, A.; Bezbradica, D. Novel $\beta$-galactosidase nanobiocatalyst systems for application in the synthesis of bioactive galactosides. RSC Adv. 2016, 6, 97216-97225. [CrossRef]

20. Serey, M.; Vera, C.; Guerrero, C.; Illanes, A. Immobilization of Aspergillus oryzae $\beta$-galactosidase in cation functionalized agarose matrix and its application in the synthesis of lactulose. Int. J. Biol. Macromol. 2021, 167, 1564-1574. [CrossRef]

21. Ureta, M.M.; Martins, G.N.; Figueira, O.; Pires, P.F.; Castilho, P.C.; Gomez-Zavaglia, A. Recent advances in $\beta$-galactosidase and fructosyltransferase immobilization technology. Crit. Rev. Food Sci. Nutr. 2020. [CrossRef]

22. Liu, Y.; Wang, B.; Ji, X.; He, Z. Self-assembled protein-enzyme nanoflower-based fluorescent sensing for protein biomarker. Anal. Bioanal. Chem. 2018, 410, 7591-7598. [CrossRef] [PubMed]

23. Talens-Perales, D.; Fabra, M.J.; Martínez-Argente, L.; Marín-Navarro, J.; Polaina, J. Recyclable thermophilic hybrid proteininorganic nanoflowers for the hydrolysis of milk lactose. Int. J. Biol. Macromol. 2020, 151, 602-608. [CrossRef] [PubMed]

24. Fabra, M.J.; Talens-Perales, D.; Roman-Sarmiento, A.; López-Rubio, A.; Polaina, J. Effect of biopolymer matrices on lactose hydrolysis by enzymatically active hydrogel and aerogels loaded with $\beta$-galactosidase nanoflowers. Food Hydrocoll. 2021, 111, 106220. [CrossRef]

25. Lei, Z.; Gao, C.; Chen, L.; He, Y.; Ma, W.; Lin, Z. Recent advances in biomolecule immobilization based on self-assembly: Organic-inorganic hybrid nanoflowers and metal-organic frameworks as novel substrates. J. Mater. Chem. B 2018, 6, 1581-1594. [CrossRef] [PubMed]

26. Somturk, B.; Yilmaz, I.; Altinkaynak, C.; Karatepe, A.; Özdemir, N.; Ocsoy, I. Synthesis of urease hybrid nanoflowers and their enhanced catalytic properties. Enzym. Microb. Technol. 2016, 86, 134-142. [CrossRef]

27. Li, Y.; Fei, X.; Liang, L.; Tian, J.; Xu, L.; Wang, X.; Wang, Y. The influence of synthesis conditions on enzymatic activity of enzyme-inorganic hybrid nanoflowers. J. Mol. Catal. B Enzym. 2016, 133, 92-97. [CrossRef]

28. Guerrero, C.; Vera, C.; Serna, N.; Illanes, A. Immobilization of Aspergillus oryzae B-galactosidase in an agarose matrix functionalized by four different methods and application to the synthesis of lactulose. Bioresour. Technol. 2017, 232, 53-63. [CrossRef]

29. Urrutia, P.; Bernal, C.; Wilson, L.; Illanes, A. Use of chitosan heterofunctionality for enzyme immobilization: $\beta$-galactosidase immobilization for galacto-oligosaccharide synthesis. Int. J. Biol. Macromol. 2018, 116, 182-193. [CrossRef]

30. Huerta, L.M.; Vera, C.; Guerrero, C.; Wilson, L.; Illanes, A. Synthesis of galacto-oligosaccharides at very high lactose concentrations with immobilized $\beta$-galactosidases from Aspergillus oryzae. Process Biochem. 2011, 46, 245-252. [CrossRef]

31. Ansari, S.; Husain, Q. Immobilization of Aspergillus oryzae $\beta$ galactosidase on concanavalin A-layered calcium alginate-cellulose beads and its application in lactose hydrolysis in continuous spiral bed reactors. Pol. J. Chem. Technol. 2011, 13, 15-20. [CrossRef]

32. Gaur, R.; Pant, H.; Jain, R.; Khare, S.K. Galacto-oligosaccharide synthesis by immobilized Aspergillus oryzae $\beta$-galactosidase. Food Chem. 2006, 97, 426-430. [CrossRef]

33. Albayrak, N.; Yang, S.T. Immobilization of $\beta$-galactosidase on fibrous matrix by polyethyleneimine for production of galactooligosaccharides from lactose. Biotechnol. Prog. 2002, 18, 240-251. [CrossRef] [PubMed]

34. Souza, C.J.F.; Garcia-Rojas, E.E.; Souza, C.S.F.; Vriesmann, L.C.; Vicente, J.; de Carvalho, M.G.; Petkowicz, C.L.O.; Favaro-Trindade, C.S. Immobilization of $\beta$-galactosidase by complexation: Effect of interaction on the properties of the enzyme. Int. J. Biol. Macromol. 2019, 122, 594-602. [CrossRef] [PubMed]

35. Guerrero, C.; Aburto, C.; Súarez, S.; Vera, C.; Illanes, A. Improvements in the production of Aspergillus oryzae $\beta$-galactosidase crosslinked aggregates and their use in repeated-batch synthesis of lactulose. Int. J. Biol. Macromol. 2020, 142, 452-462. [CrossRef]

36. Guerrero, C.; Vera, C.; Araya, E.; Conejeros, R.; Illanes, A. Repeated-batch operation for the synthesis of lactulose with $\beta$ galactosidase immobilized by aggregation and crosslinking. Bioresour. Technol. 2015, 190, 122-131. [CrossRef] [PubMed]

37. Illanes, A.; Wilson, L. Parameters for the evaluation of immobilized enzymes under process conditions. Methods Mol. Biol. 2020, 2100, 65-81.

38. Lin, Y.F.; Cheng, C.W.; Shih, C.S.; Hwang, J.K.; Yu, C.S.; Lu, C.H. MIB: Metal ion-binding site prediction and docking server. J. Chem. Inf. Model. 2016, 56, 2287-2291. [CrossRef] [PubMed]

39. Aires, A.; Llarena, I.; Moller, M.; Castro-Smirnov, J.; Cabanillas-Gonzalez, J.; Cortajarena, A.L. A simple approach to design proteins for the sustainable synthesis of metal nanoclusters. Angew. Chem. Int. Ed. 2019, 58, 6214-6219. [CrossRef]

40. Martínez-Rosell, G.; Giorgino, T.; De Fabritiis, G. PlayMolecule ProteinPrepare: A web application for protein preparation for molecular dynamics simulations. J. Chem. Inf. Model. 2017, 57, 1511-1516. [CrossRef]

41. Orme, C.A.; Giocondi, J.L. Model systems for formation and dissolution of calcium phosphate minerals. Handb. Biominer.: Biol. Asp. Struct. Form. 2008, 2, 135-157.

42. Tung, M.S. Calcium phosphates: Structure, composition, solubility, and stability. In Calcium Phosphates in Biological and Industrial Systems; Amjad, Z., Ed.; Springer: Boston, MA, USA, 1998; pp. 1-19. [CrossRef]

43. Kim, K.H.; Jeong, J.M.; Lee, S.J.; Choi, B.G.; Lee, K.G. Protein-directed assembly of cobalt phosphate hybrid nanoflowers. J. Colloid Interface Sci. 2016, 484, 44-50. [CrossRef] [PubMed] 
44. Sun, J.; Ge, J.; Liu, W.; Lan, M.; Zhang, H.; Wang, P.; Wang, Y.; Niu, Z. Multi-enzyme co-embedded organic-inorganic hybrid nanoflowers: Synthesis and application as a colorimetric sensor. Nanoscale 2014, 6, 255-262. [CrossRef] [PubMed]

45. Zhu, X.; Huang, J.; Liu, J.; Zhang, H.; Jiang, J.; Yu, R. A dual enzyme-inorganic hybrid nanoflower incorporated microfluidic paperbased analytic device ( $\mu$ PAD) biosensor for sensitive visualized detection of glucose. Nanoscale 2017, 9, 5658-5663. [CrossRef] [PubMed]

46. Wang, L.B.; Wang, Y.C.; He, R.; Zhuang, A.; Wang, X.; Zeng, J.; Hou, J.G. A new nanobiocatalytic system based on allosteric effect with dramatically enhanced enzymatic performance. J. Am. Chem. Soc. 2013, 135, 1272-1275. [CrossRef]

47. Vera, C.; Córdova, A.; Aburto, C.; Guerrero, C.; Suárez, S.; Illanes, A. Synthesis and purification of galacto-oligosaccharides: State of the art. World J. Microbiol. Biotechnol. 2016, 32, 197. [CrossRef] [PubMed]

48. Guerrero, C.; Aburto, C.; Suárez, S.; Vera, C.; Illanes, A. Effect of the type of immobilization of $\beta$-galactosidase on the yield and selectivity of synthesis of transgalactosylated oligosaccharides. Biocatal. Agric. Biotechnol. 2018, 16, 353-363. [CrossRef]

49. Hoyos, P.; Bavaro, T.; Perona, A.; Rumbero, A.; Tengattini, S.; Terreni, M.; Hernaíz, M.J. Highly efficient and sustainable synthesis of neoglycoproteins using galactosidases. ACS Sustain. Chem. Eng. 2020, 8, 6282-6292. [CrossRef]

50. Zhang, Y.; Zhong, Q. Freeze-dried capsules prepared from emulsions with encapsulated lactase as a potential delivery system to control lactose hydrolysis in milk. Food Chem. 2018, 241, 397-402. [CrossRef]

51. Vera, C.; Guerrero, C.; Conejeros, R.; Illanes, A. Synthesis of galacto-oligosaccharides by $\beta$-galactosidase from Aspergillus oryzae using partially dissolved and supersaturated solution of lactose. Enzym. Microb. Technol. 2012, 50, 188-194. [CrossRef] 